\title{
Pengembangan metode valuasi ekonomi dampak langsung spesies asing invasif berbasis kompetisi makanan pada ekosistem perairan
}

\section{Development of economic valuation method for the direct impact of alien invasive species based on food competition in aquatic ecosystems}

\author{
Taryono Kodiran ${ }^{\mathrm{a}}$, Ali Mashar ${ }^{\mathrm{a}}$, Riska Febriana ${ }^{\mathrm{a}}$, Erin R. Nurulhayati ${ }^{\mathrm{a}}$, Athifah Nurulhafidzah ${ }^{\mathrm{a}}$, Yusli Wardiatno ${ }^{\mathrm{ab}}$ \\ ${ }^{a}$ Departemen Manajemen Sumberdaya Perairan, Fakultas Perikanan dan Ilmu Kelautan Institut Pertanian Bogor, Kampus IPB \\ Darmaga Bogor, 16680, Indonesia [+62-251-8622932] \\ ${ }^{\mathrm{b}}$ Pusat Penelitian Lingkungan Hidup, Lembaga Penelitian dan Pengabdian kepada Masyarakat, Institut Pertanian Bogor, Kampus \\ IPB Darmaga Bogor, 16680, Indonesia
}

\section{Article Info:}

Received: 06 - 03 - 2020

Accepted: 19 - 05 - 2020

\section{Keywords:}

Cherax quadricarinatus, economic valuation, food competition, Lido lake, niche overlap, Procambarus clarkii

Corresponding Author: Taryono Kodiran

Departemen Manajemen Sumberdaya Perairan, Fakultas Perikanan dan Ilmu Kelautan, Institut Pertanian Bogor; Tel. +62-251-8624360

Email:

taryono@apps.ipb.ac.id

\begin{abstract}
Alien crayfish species (Cherax quadricarinatus and Procambarus clarkii) have been found in some Indonesian area and demonstrated invasive species characters. Despite their economic benefit the crayfish has potential ecologically disadvantage to be valuated. This study aimed to develop a valuation method to estimate economic loss due to alien invasive species on food competition basis in an aquatic ecosystem. This approach was conducted by estimating the potential loss due to food competition between invasive species and its inferior competitor. The case study was carried out in the Lido Lake and in an aquaculture site at Cisaat, Sukabumi - West Java. The research results that economic loss due to the disappearance of native Macrobrachium sintangense caused by the existence of single male $\mathrm{C}$. quadricarinatus is 784 IDR and 1096 IDR for the female in Lido Lake. The potential loss of M. rosenbergii due to the single P. clarkii is 1416.76 IDR. The difference in economic loss is constituted by the quantity of feed taken by the invasive species, and the economic value of competitive inferior species. This method is clearly explained in the method section and is simple to use, but more understandable for limited economics background stakeholders. However, this approach needs a robust biological dynamic model. The valuation results become an important reference for the policymaker to develop risk analysis in concern of introduced invasive species into an ecosystem. For holistic economic loss value valuation, further studies covering space competition and potential harmful pathogen carriers are warranted.
\end{abstract}

How to cite (CSE Style $8^{\text {th }}$ Edition):

Kodiran T, Mashar A, Febriana R, Nurulhayati ER, Nurulhafidzah A, Wardiatno Y. 2020. Pengembangan metode valuasi ekonomi dampak langsung spesies asing invasif berbasis kompetisi makanan pada ekosistem perairan. JPSL 10(2): 198-208. http://dx.doi.org/10.29244/jps1.10.2.198-208. 


\section{PENDAHULUAN}

Di berbagai belahan dunia, spesies invasif telah menjamah ekosistem dataran tinggi seperti pegunungan Nepal (Kunwar dan Acharya, 2013), dataran rendah (Mostert et al., 2013), ekosistem teresterial dan perairan (tawar dan laut) (Gallardo et al., 2015), ekosistem kepulauan maupun daratan (Russel et al., 2017; Spatz et al., 2017), baik hewan maupun tumbuhan (Gallardo et al., 2015). Dampak spesies invasif telah menjadi perhatian Darwin dan ahli biologi lainnya sejak lebih dari satu setengah abad silam (Ludsin dan Wolfe, 2001; Cadotte, 2006). Spesies introduksi/asing dilaporkan telah menjadi ancaman penting bagi masyarakat maupun biota dunia (Ludsin dan Wolfe, 2001). Dampak negatif penyebaran spesies asing invasif dapat mengancam ekosistem, menurunkan jumlah spesies asli, dan menimbulkan dampak negatif pada aspek sosial ekonomi (Ludsin dan Wolfe, 2001; Sarat et al., 2015). Penurunan keanekaragaman hayati karena keberadaan spesies invasif merupakan proses awal menuju kepunahan spesies tertentu (Hestimaya, 2010). Hal yang mendasar adalah distribusi spesies invasif sangat terkait dengan dinamika relasi antar penduduk dunia, melalui transportasi, perdagangan, dan faktor antropogenis lainnya (Gallardo et al., 2015; Turbelin et al., 2017), sehingga secara global terjadi peningkatan harapan akan adanya aksi untuk mengatasi isu negatif adanya spesies invasif (Turbelin et al., 2017).

Salah satu spesies invasif yang telah berkembang di berbagai belahan dunia adalah lobster air tawar, Cherax quadricarinatus dan Procambarus clarkii. Kedua jenis lobster air tawar tersebut telah diindentifikasi menjadi satu kelompok utama spesies invasif pada ekosistem perairan baik di Eropa (Lodge et al., 2000; Gherardi dan Acquistapace, 2007), Amerika Utara (Taylor et al., 1996; Taylor et al., 2007) dan Asia (Patoka et al., 2016; Putra et al., 2018). Solano et al., (2017) menyatakan keberadaan lobster air tawar dapat menyebabkan hilangnya spesies asli, seperti kasus dugaan hilangnya udang regang (Macrobrachium sintangense) di Danau Lido (Aprila, 2018). C. quadricarinatus telah berkembang, tidak hanya di Australia, negara asal mereka dengan mendiami sungai dan danau, tetapi juga di banyak negara seperti Singapura (Ahyong dan Yeo, 2007), Cina, Israel, Meksiko, Amerika Serikat, dan Argentina (Tropea et al., 2010), dan juga di Indonesia (Patoka et al., 2016). P. clarkii pun telah dilaporkan keberadaannya di Indonesia dan membawa potensi patogen (Putra et al., 2018). Lodge et al., (2012) mengingatkan, disamping adanya keuntungan ekonomi, namun dalam jangka panjang dampak negatif pada jasa ekosistem seringkali bernilai lebih besar.

Estimasi nilai atau kerugian ekonomi terhadap sumber daya cukup banyak dilakukan, misalnya terhadap sumber daya perikanan atau ekosistem perairan (Aini et al., 2018; Hermanto et al., 2019). Dampak negatif spesies invasif termasuk lobster secara umum didasarkan pada dampak ekologis maupun ekonomis. Oleh karena itu, secara umum perlu pendekatan yang tepat untuk menganalisisnya. Metode untuk penilaian dampak spesies invasif pada ekosistem perairan hingga saat ini belum ada yang mengembangkan. Pada tulisan ini dampak ekonomi spesies invasif lobster air tawar mencakup tiga komponen pokok, yaitu: biaya kerusakan (lingkungan), biaya pengelolaan dan dampak pada spesies lain. Dampak ekonomi langsung pada spesies lain lebih jelas dan mudah diterima oleh non-ekonomis. Analisis ini melihat dampak kompetisi (ruang dan makanan) dan potensi pembawa organisme pathogen yang berbahaya bagi spesies lain. Walaupun mudah diterima, tetapi pendekatan ini masih jarang dilakukan, karena harus didukung oleh data bio-ekologi, termasuk perilaku kompetisinya.

Salah satu pendekatan penilaian dampak ekonomi langsung adalah pendekatan nilai dampak kompetisi makanan dengan pesaing yang kalah (inferior competitor). Perhitungan ini dapat dengan jelas memberikan gambaran besaran nilai dampak ekonominya serta memberikan arahan pengambil kebijakan lebih lugas. Namun dampak ekonomi ini juga dapat dikoreksi (off-setted) dengan nilai kontribusi spesies tersebut pada ekonomi lokal, sehingga akan terlihat nilai ekonomi bersih dari spesies invasif lobster air tawar. Tujuan paper ini adalah mengembangkan metode perhitungan valuasi spesies invasif melalui pendekatan kompetisi makanan antara spesies invasif dengan pesaing yang kalah (inferior competitor). 


\section{METODE}

\section{Lokasi dan Waktu Penelitian}

Pengambilan data primer (bio-ekologis) untuk spesies C. quadricarinatus dilakukan di Danau Lido sedangkan spesies $P$. clarkii dilakukan di sebuah pusat pembesaran lobster air tawar di daerah Cisaat, Kabupaten Sukabumi pada tahun 2018.

\section{Metode Pengumpulan Data}

Sampling individu spesies C. quadricarinatus ditangkap menggunakan bubu di Danau Lido sebanyak 40 titik sampling di kedalaman perairan 2, 3, 4, dan 6 meter. Pemberian tanda (marking) dilakukan pada sampel yang telah diambil sebelum dilepas dan kemudian tertangkap lagi (CCMR = Capture Mark Release and Recapture). Pengambilan data primer P. clarkii dilakukan di areal budidaya ikan Cisaat, Kabupaten Sukabumi. Data yang diambil mencakup panjang karapas, pertumbuhan, ukuran pertama kali ditangkap, umur lobster pertama kali ditangkap, kebutuhan makanan. Data harga masing-masing spesies invasive diperoleh pada nelayan dan pembudidaya di lokasi sampling. Data dua spesies kompetitor yang kalah, yakni udang regang (Macrobrachium sintangense) dan udang galah (Macrobrachium rosenbergii) didasarkan pada penelitian sebelumnya.

\section{Metode Analisis Data}

\section{Pendugaan Kelimpahan}

Data yang diperoleh dari sampling CMRR di Danau Lido dianalisis untuk menghitung kelimpahan dengan Metode Schnable (Ogle, 2013), dengan rumus sebagai berikut:

dengan ketentuan:

$$
N=\frac{\sum_{i=1}^{m} M_{i} C_{i}}{\sum_{i=1}^{m} R_{i}}
$$

$\mathrm{N}=$ jumlah total populasi lobster (ekor)

$\mathrm{Mi}=$ jumlah lobster yang ditandai sebelumnya waktu I (ekor)

$\mathrm{Ci}=$ jumlah lobster yang ditangkap pada waktu I (ekor)

$\mathrm{Ri}=$ jumlah lobster yang ditandai tertangkap pada waktu I (ekor)

\section{Analisis Kebutuhan Makanan}

Untuk dapat mengestimasi kebutuhan makanan, diperlukan tiga data panjang atau berat ikan, estimasi pertumbuhan ikan harian, pertambahan bobot harian dan estimasi umur ikan. Pada spesies C. quadricarinatus yang hidup diperairan bebas, analisis kebutuhan makanan diperoleh dari estimasi kebutuhan makanan yang dikonsumsi sampai dengan umur lobster pada saat ditangkap. Jumlah keseluruhan makanan yang dihabiskan oleh satu individu, merupkanan akumulasi dari makanan yang dimakan oleh individu tersebut sampai dengan umur ditangkap.

Berdasarkan sampling individu, diperoleh bobot rata-rata lobster yang tertangkap. Estimasi panjang lobster rata-rata yang tertangkap dapat dilakukan dengan persamaan hubungan panjang bobot lobster sebagai berikut (Effendi, 2002).

$$
w_{t}=a L_{t}^{b} \text { atau } L_{t}=\left(\frac{w_{t}}{a}\right)^{\frac{1}{b}}
$$

Estimasi pertumbuhan harian udang didekati dari pertumbuhan panjang udang, sesuai dengan formula dari von Bartalanffy (Sparre dan Venemma, 1999).

$$
\mathrm{L}_{\mathrm{t}}=\mathrm{L}_{\infty}\left[1-\mathrm{e}^{-\mathrm{K}\left(\mathrm{t}-\mathrm{t}_{0}\right)}\right]
$$


Sedangkan umur udang yang tertangkap didekati dari panjang ikan yang tertangkap (Lt) dan dapat diduga dari persamaan berikut.

$$
\mathrm{t}=\mathrm{t}_{0}-\frac{1}{\mathrm{~K}} \times \operatorname{Ln}\left(1-\frac{\mathrm{Lt}}{\mathrm{L}_{\infty}}\right)
$$

Pada penelitian ini analisis pertumbuhan ikan dilakukan berdasakan data bulanan. Sementara untuk analisis yang lebih rinci diperlukan pertumbuhan ikan harian, sehingga nilai konstanta $\mathrm{K}$ dan $\mathrm{t}_{0}$ dikonversi menjadi $\mathrm{K}$ dan $\mathrm{t}_{0}$ harian. Bila diasumsikan 1 bulan sebagai 30 hari, maka nilai konstanta $\mathrm{K}$ menjadi nilai $\mathrm{K}$ bulanan dibagi 30. Sedangkan $t_{0}$ diperoleh dari $t_{0}$ bulanan dikalikan 30. Kebutuhan makanan harian (fdt) merupakan nilai proporsi (c) dari bobot individu pada hari ke-t $(\mathrm{Wt})$ :

$$
f d_{t}=c \mathrm{Wt}
$$

Total kebutuhan makanan satu individu (fi) adalah penjumlahan dari kebutuhanan makanan harian sampai dengan umur udang ditangkap ( $\mathrm{d}$ hari) dan diformulasikan sebagai berikut:

$$
\mathrm{fi}=\mathrm{c} \sum_{t=1}^{d} W_{t}
$$

Keterangan:

$\mathrm{a}, \mathrm{b}=$ parameter

$\mathrm{c} \quad=$ asumsi proporsi kebutuhan makanan dari bobot tubuh lobster (\%)

fdt $=$ kebutuhan makanan ikan pada waktu $\mathrm{t}$ (gram)

$\mathrm{fi}=$ kebutuhan makan lobster total (gram)

$\mathrm{Lt}=$ ukuran panjang karapas pada saat umur ke $\mathrm{t}(\mathrm{mm})$

$\mathrm{L}_{\infty}=$ panjang karapas asimtotik $(\mathrm{mm})$

$\mathrm{K}=$ koefisien pertumbuhan spesies (bulanan dikonversi ke harian)

$\mathrm{t}_{0} \quad=$ umur spesies pada saat panjang karapasnya sama dengan nol (bulan dikonversi ke hari)

$\mathrm{t}=$ umur lobster pada saat pertama kali tertangkap (bulan dikonversi ke hari)

$\mathrm{d} \quad=$ umur udang waktu ditangkap (hari)

$\mathrm{w}_{\mathrm{t}}=$ bobot ikan pada waktu $\mathrm{t}$ (bulan dikonversi ke hari)

Pada kondisi belum diperoleh hubungan panjang dan berat lobster air tawar dan atau kompetitor inferiornya atau salah satunya secara harian $(\mathrm{t}=$ harian $)$, maka diasumsikan pertumbuhan linear. Pertambahan bobot tubuh harian ke-t $\Delta W t$ diasumsikan sama setiap hari, yang dirumuskan sebagai pertambahan bobot akhir waktu ditangkap $\left(W_{d}\right)$ dikurangi bobot awal $\left(W_{0}\right)$ dibagi umur udang sampai dengan ditangkap $(\mathrm{d})$.

$$
\Delta W t=\frac{W_{d}-W_{0}}{d}
$$

Bobot tubuh udang hari ke-t (Wt) adalah bobot tubuh waktu sebelumnya (Wt-1) ditambah pertambahan bobot harian $(\Delta W t)$ atau dalam formulasi sebagai berikut:

$$
W_{t}=W_{t-1}+\Delta W t
$$

Kebutuhan makanan diasumsikan sebagai proporsi (c) dari bobot tubuh. Sehingga total kebutuhan makanan udang harian ke-t $\left(\mathrm{fd}_{\mathrm{t}}\right)$ dan total kebutuhan makanan (fi) sampai dengan umur waktu tertangkap (d) diperoleh dengan dengan persamaan berikut:

$$
f d_{t}=\mathrm{c} W t
$$




$$
\mathrm{fi}=\mathrm{c} \sum_{i=1}^{d} W_{t}
$$

Sedangkan spesies $P$. clarkii yang dibudidayakan, kebutuhan makanan (pakan) dapat dihitung dengan formulasi sebagai berikut.

Keterangan:

$$
\mathrm{fi}=\mathrm{FCR} \times \mathrm{w}
$$

fi $\quad=$ volume makanan yang dikonsumsi total sampai ditangkap (gram)

FCR $=$ konstanta perubahan pakan menjadi bobot tubuh

$\mathrm{w} \quad=$ bobot rata-rata pada saat ditangkap (gram)

\section{Kerugian Ekonomi}

\section{Analisis individu yang hilang karena kompetisi makanan}

Analisis ini didasarkan pada kompetisi makanan antara lobster air tawar sebagai spesies invasif dengan spesies yang kalah berkompetisi. Jumlah makanan yang dikonsumsi satu individu lobster air tawar sampai pada ukuran yang ditangkap yang seharusnya menjadi makanan kompetitor yang kalah bersaing, menggambarkan potensi jumlah individu (ekor) yang hilang atau menjadi korbanan dari adanya lobster air tawar. Perhitungan ini dapat dilihat sebagai berikut:

dengan ketentuan:

$$
\mathrm{Nci}=\frac{\mathrm{fi}}{\mathrm{fci}}
$$

$\mathrm{Nci}=$ jumlah individu yang hilang akibat kompetisi makanan dengan satu ekor spesies invasive (ekor)

fi = jumlah makanan yang dikonsumsi oleh satu individu spesies invasive sampai ukuran ditangkap (gram/ekor)

fci $=$ jumlah makanan yang dikonsumsi oleh satu invididu spesies competitor inferior sampai ukuran ditangkap (gram/ekor)

\section{Total Kerugian Ekonomi}

Total kerugian ekonomi dari adanya invasive spesies dinyatakan sebagai berikut:

dengan ketentuan:

$$
\mathrm{EL}=\mathrm{Nci} \times \mathrm{Pci}
$$

$\mathrm{EL}=$ potensi kerugian ekonomi akibat hilangnya spesies kompetitor inferior $(\mathrm{Rp})$

Nci $=$ jumlah individu yang hilang akibat kompetisi makanan (ekor atau $\mathrm{kg}$ )

$\mathrm{Pci}=$ harga individu yang hilang akibat kompetisi makanan (Rp/ekor atau Rp/kg)

\section{HASIL DAN PEMBAHASAN}

\section{Spesies yang Diduga Berkompetisi Makanan}

Analisis ini didasarkan pada dua spesies lobster air tawar pada lingkungan perairan yang berbeda. Spesies C. quadricarinatus di Danau Lido dan P. clarkii di wilayah perairan budidaya di daerah Cisaat, Kabupaten Sukabumi. C. quadricarinatus berpotensi berkompetisi makanan dengan udang regang (M. sintangense) di perairan Danau Lido, sedangkan $P$. clarkii berpotensi berkompetisi makanan dengan udang galah $(M$. rosenbergii) di wilayah perairan budidaya di Cisaat, Sukabumi.

Simulasi analisis ini didasarkan pada potensi kerugian karena adanya kompetisi makanan, sehingga berpotensi menghilangkan spesies pesaing yang kalah (C. quadricarinatus, M. sintangense, dan P. clarkii, $M$. rosenbergii). Nilai kerugian ini dipengaruhi dua faktor hal pokok yaitu: (1) perbandingan estimasi jumlah makanan yang dihabiskan oleh spesies invasive dan spesies pesaing yang kalah sebagai faktor biologi, dan (2) perbandingan harga relatif antara harga komoditas spesis invasive dengan kompetitor asli (native) yang hilang 202 
tersebut sebagai faktor ekonomis. Dinamika faktor biologis cenderung untuk stabil, bila diasumsikan kondisi ekologis yang sama, sedangkan faktor ekonomis akan sangat berbeda nilainya tergantung nilai masing-masing komoditas tersebut pada kondisi sosial ekonomi setempat. Sehingga, walaupun faktor biologis cenderung tetap, tetapi bila nilai ekonomis komoditas tersebut berbeda, maka nilai korbanan dari adanya spesies invasif tersebut akan sangat berbeda.

Di perairan Danau Lido terdapat tiga spesies krustasea yaitu lobster air tawar (C. quadricarinatus), udang regang (M. sintangense) dan udang putih (M. lanchesteri). C. quadricarinatus merupakan spesies introduksi di perairan Danau Lido pada tahun 1990-an yang dipelihara di karamba, yang diduga mempunyai relung ekologi dan makanan yang sama dengan udang regang dan udang putih. Pola ini juga ditemukan di sungai maupun antar beberapa sungai setelah diintroduksi di Afrika Selatan dan Swaziland (Nunes et al., 2017). Aprila (2018) menyatakan bahwa udang regang di Danau Lido akhir-akhir ini sudah tidak ditemukan lagi, tetapi udang putih masih ada.

P. clarkii dan udang galah mempunyai kebiasaan makanan yang sama tetapi dengan komposisi yang berbeda. Jenis makanan tersebut adalah tumbuhan, alga, krustasea, moluska, insekta, rotifera, detritus dan lainnya (Wato dan Okoth, 2014; Tjahjo et al., 2004). P. clarkii termasuk jenis lobster air tawar yang cenderung bersifat herbivor, dan bersifat agresif, sehingga berpotensi menjadi kompetitor makanan bagi udang galah ( $M$. rosenbergii).

\section{Kerugian Ekononomi Akibat C. quadricanatus di Danau Lido}

Hasil analisis mendapatkan parameter pertumbuhan C. quadricanatus di Danau Lido seperti terlihat dalam Tabel 1. Berdasarkan parameter pada tabel tersebut, maka dapat diestimasi umur lobster jantan adalah 2.56 bulan atau 76.82 hari dan lobster betina adalah 2.82 bulan atau 84.5 hari. Data ini digunakan untuk mengestimasi jumlah makanan yang dimakan oleh lobster sampai tertangkap. Asumsi persentase makanan $C$. quadricarinatus yang digunakan yaitu 5\% dari bobot tubuh per hari (Rihardi et al., 2013), sehingga total kebutuhan makanan C. quadricarinatus dapat diestimasi.

Tabel 1 Parameter pertumbuhan C. quadricanatus di Danau Lido

\begin{tabular}{clccc}
\hline \multirow{2}{*}{ No } & & \multirow{2}{*}{ Parameter } & Jantan & Benis Kelamin \\
\cline { 3 - 4 } & & $\mathrm{L}_{\max }$ & 75 & 70 \\
2 & $\mathrm{~L}_{\text {inf }}$ & 82.5 & 80.5 \\
3 & $\mathrm{~K}$ bulan & 0.22 & 0.23 \\
4 & $\mathrm{t}_{0}$ bulan & -0.237 & -0.2541 \\
5 & $1 / \mathrm{k}$ & 4.5455 & 4.3478 \\
6 & $\mathrm{Lc}$ & 37.92 & 40.85 \\
\hline
\end{tabular}

Pendugaan kelimpahan C. quadricarinatus di Danau Lido dengan Metode Schnable mendapat estimasi jumlah individu $C$. quadricarinatus sebanyak $2936 \pm 22$ individu atau diasumsikan sebesar 2958 individu. Hasil sampling mendapatkan perbandingan populasi jantan dengan betina di Danau Lido adalah 1:1.25. Harga C. quadricarinatus pada tingkat nelayan adalah $\mathrm{Rp} 150000 / \mathrm{kg}$.

Kompetitif inferior dari C. quadricarinatus di Danau Lido adalah udang regang ( $M$. sintangense). Penelitian terdahulu menyatakan umur udang regang yang tertangkap adalah 6 bulan atau 180 hari (Said et al., 2014). Sedangkan, asumsi makanan udang regang sebesar 3\% per hari (Mayasari dan Said, 2014) dari berat maksimum yaitu 5 gram/ekor. Harga udang regang di tingkat nelayan adalah Rp 80000/kg atau Rp 400 per/ekor (pada bobot rata-rata 5 gram per ekor atau 200 ekor per kilogram). Kerugian atas spesies $C$. quadricarinattus berupa potensi hilangnya udang regang (M. sintangense) di Danau Lido dapat dilihat dalam Tabel 2. 
Kodiran T, Mashar A, Febriana R, Nurulhayati ER, Nurulhafidzah A, Wardiatno Y

Tabel 2 Perhitungan kerugian adanya spesies invasif $C$. quadricanatus berupa potensi hilangnya udang regang (M. sintangense) di Danau Lido

\begin{tabular}{|c|c|c|c|c|}
\hline \multirow{2}{*}{ Parameter } & \multirow{2}{*}{ Satuan } & \multicolumn{2}{|c|}{ Lobster air tawar } & \multirow{2}{*}{ Udang regang } \\
\hline & & Jantan & Betina & \\
\hline Estimasi umur ketika ditangkap & hari & 100 & 113 & 180 \\
\hline Bobot rata-rata ditangkap & $\mathrm{g}$ & 13.8 & 17.45 & 5 \\
\hline $\begin{array}{l}\text { Asumsi kebutuhan makanan dari } \\
\text { bobot tubuh }\end{array}$ & $\%$ & 5 & 5 & 3 \\
\hline $\begin{array}{l}\text { Kebutuhan makanan sampai } \\
\text { tertangkap }\end{array}$ & $\mathrm{g}$ & 24.88 & 33.74 & 13.57 \\
\hline $\begin{array}{l}\text { Jumlah udang regang yang hilang } \\
\text { yang diakibatkan oleh } 1 \text { ekor } \\
\text { lobster }\end{array}$ & ekor & 1.83 & 2.49 & \\
\hline Harga udang & $\mathrm{Rp} / \mathrm{kg}$ & 150000 & 150000 & 80000 \\
\hline Harga udang per ekor & Rp/ekor & 2070 & 2617.50 & 400 \\
\hline $\begin{array}{l}\text { Kerugian penangkap udang regang } \\
\text { yang diakibatkan oleh } 1 \text { ekor } \\
\text { lobster }\end{array}$ & $\mathrm{Rp}$ & 733.27 & 994.42 & \\
\hline Jumlah total lobster di Danau Lido & ekor & 1315 & 1643 & \\
\hline $\begin{array}{l}\text { Kerugian penangkap udang regang } \\
\text { yang diakibatkan oleh total lobster }\end{array}$ & $\mathrm{Rp}$ & 964244.04 & 1633826.20 & \\
\hline $\begin{array}{l}\text { Total kerugian penangkap udang } \\
\text { regang }\end{array}$ & $\mathrm{Rp}$ & & 2598070.24 & \\
\hline $\begin{array}{l}\text { Total nilai dari penjualan lobster di } \\
\text { Danau Lido }\end{array}$ & $\mathrm{Rp}$ & & 7022602.50 & \\
\hline $\begin{array}{l}\text { Nilai bersih dari penjualan total } \\
\text { lobster di Danau Lido }\end{array}$ & $\mathrm{Rp}$ & & 4424532.26 & \\
\hline
\end{tabular}

Keterangan: pertumbuhan lobster air tawar diasumsikan mengikuti model von Bartalanffy (Sparre dan Venemma, 1999), sedangkan pertumbuhan udang regang digunakan pendekatan pertumbuhan linear

\section{Potensi Kerugian Ekononomi Akibat P. clarkii di daerah Cisaat, Kabupaten Sukabumi}

Sifat $P$. clarkii yang agresif dan rakus, sehingga berpotensi menjadi ancaman bagi spesies lain yang dipelihara dalam satu wadah (Afni, 2008). Spesies ini merupakan hewan yang polytrophic benthic omnivores (Romaire, 2017), yaitu pemakan segala yang mampu menurunkan nutrisi dari banyak zat organik. Rata-rata lobster air tawar yang dipanen untuk dijual adalah ukuran 9.18 gram/ekor.

Lobster air tawar (P. clarkii) dan udang galah (M. rosenbergii) merupakan spesies yang dibudidayakan di lokasi penelitian. Perhitungan konversi pakan ke bobot tubuh (FCR) untuk P. clarkii adalah 1.8 (Xiao et al., 2014) dan udang galah (M. rosenbergii) 1.4 (Tahir dan Pasaribu, 2003). Hasil penelitian menunjukkan bahwa bobot rata-rata $P$. clarkii yang dipanen untuk dijual 9.18 gram/ekor, dan $M$. rosenbergii dipanen untuk dijual pada ukuran 33.33 gram/ekor. Potensi kerugian akibat spesies invasive $P$. clarkii akibat hilangnya $M$. rosenbergii yang didasarkan pada kompetisi makanan dapat dilihat dalam Tabel 3.

Pada kasus C. quadricarinatus, kerugian akibat adanya invasive spesies ini lebih rendah nilainya dibandingkan pada kasus $P$. clarkii. Secara biologis ukuran udang $C$. quadricarinatus lebih tinggi dibandingkan dengan $P$. clarkii dan ukuran pesaing yang kalah lebih besar sehingga jumlah individu yang hilang lebih kecil. Tetapi karena harga udang galah sebagai spesies yang kalah akibat adanya $P$. clarkii yang jauh lebih besar, maka nilai korbanan adanya $P$. clarkii lebih tinggi. Bahkan nilai bersih dari komoditas ini 
adalah negative atau rugi. Nilai kerugian ini akan semakin besar, bila potensi kerugian invasive spesies yang lain seperti relasi predator-prey atau bakteri patogen, kompetisi ruang dihitung.

Tabel 3 Potensi kerugian ekonomi akibat spesies invasif $P$. clarkii akibat hilangnya $M$. rosenbergii

\begin{tabular}{lccc}
\hline \multicolumn{1}{c}{ Parameter } & Satuan & P. clarkii & M. rosenbergii \\
\hline Bobot rata-rata per ekor & gram & 9.18 & 33.33 \\
FCR & - & 1.80 & 1.40 \\
Total kebutuhan jumlah pakan per ekor & gram & 16.53 & 46.67 \\
Jumlah per kilogram & ekor & 109 & 30 \\
Potensi spesies kompetitor yang hilang akibat satu ekor & ekor & & 0.35 \\
spesies invasive & & & \\
Harga per kilogram & $\mathrm{Rp}$ & 50000 & 120000 \\
Harga spesies per ekor & $\mathrm{Rp}$ & 459 & 4000 \\
$\begin{array}{l}\text { Potensi nilai spesies kompetitor yang hilang akibat satu ekor } \\
\text { spesies invasif }\end{array}$ & $\mathrm{Rp}$ & & 1416.76 \\
$\begin{array}{l}\text { Potensi kerugian akibat 1 kilogram spesies invasif } \\
\text { Nilai manfaat bersih satu ekor invasif spesies }\end{array}$ & $\mathrm{Rp}$ & & 154330.71 \\
Nilai manfaat bersih satu kilogram spesies invasif & $\mathrm{Rp} / \mathrm{ekor}$ & & $(957.76)$ \\
\hline
\end{tabular}

Keterangan: nilai dalam tanda kurung menunjukan nilai negatif atau kerugian

Keterbatasan analisis ini model biologisnya masih sederhana. Namun demikian nilai estimasi biaya korbanan atas adanya spesies invasive sudah dapat diestimasi dengan pendekatan yang lebih mudah dimengerti terutama bagi para pihak dengan pemahaman konsep ekonomis yang terbatas. Pendekatan penilaian ini merupakan sebagian dari metode perhitungan kerugian ekonomi yang lebih menyeluruh, yang menurut Hanley dan Robert (2019) secara garis besar mencakup dampak positif dan negatif bagi kesejahteraan manusia (human well-being) maupun produksi. Pendekatan yang dilakukan ini merupakan pendekatan penilaian manfaat langsung yang didasarkan pada nilai pasar (market price).

Perring et al., (2002) menyatakan bahwa nilai ekonomi korbanan dampak spesies invasive bukan hanya nilai kerusakan dan biaya pengendalian, tetapi juga dampak pada ekosistem serta besarnya penduduk yang bergantung pada ekosistem tersebut. Oleh karenan itu, pendekatan valuasi ekonomi dampak spesies invasif harus dilakukan secara sistemik dalam ekosistem, tetapi sayangnya hal ini menjadi sangat luas dan rumit. Tinjauan terhadap studi-studi analisis dampak ekonomi invasive spesies dapat dikelompokan menjadi studi biaya secara umum, studi teoritis dan modeling, model bionomi, studi terkait perdagangan, maupun studi biaya dan manfaat pada spesies (Lovell dan Stone, 2005). Charles dan Dukes (2007) mengajukan Penilaian Ekonomi Total (TEV) yang bersandar pada nilai jasa lingkungan yang terpengaruh untuk penilaian dampak invasif spesies. Walaupun menyeluruh, masih terdapat kelemahan dalam penilaian ini yaitu tidak semua komponen mudah untuk dinilai. Penilaian berbasis nilai guna tidak langsung (indirect use), nilainya bisa sangat rendah atau tidak ada karena tidak adanya nilai-nilai non-kas pada masayarakat setempat. Pada sisi lain, beberapa nilai yang bersifat indirect use seringkali membingungkan untuk individu yang tidak mempunyai latar belakang pengetahuan ekonomi yang cukup. Oleh karenanya masih sering terjadi salah pengertian tentang besaran dampak ekonomi terutama oleh kalangan non-ekonomis karena banyaknya asumsi yang digunakan dan konsep-konsep dasar yang kuat. Nilai-nilai kerugian dalam analisis yang dilakukan pada studi ini lebih nyata dan dapat lebih mudah dipahami.

Analisis kerugian ekonomi sebagai dampak spesies invasif harus dapat mendorong perubahan sikap semua pihak untuk mendukung usaha memerangi penyebaran spesies invasive. Menurut Essl et al., (2017) penilaian dampak spesies invasive mencakup dua domain yaitu domain ilmiah (scientific domain) dengan 7 prinsip dan domain etika-politik terdiri 6 prinsip yang mencakup baik sektor privat maupun sektor publik, serta 
domain ekonomis dan ekologis (Epanchien-Neill, 2017; Huang et al., 2018). Karenanya, analisis kerugian harus bisa dipahami oleh seluruh pihak dengan baik, terutama para pengambil keputusan.

\section{KESIMPULAN}

Hasil analisis menunjukkan bahwa potensi kerugian dari adanya satu ekor spesies $C$. quadricarinatus adalah masing-masing sebesar Rp 785.27 untuk jantan dan Rp 1095.47 untuk betina akibat dari potensi hilangnya $M$. sintengense karena adanya potensi kompetisi makanan di Danau Lido. Sedangkan potensi kerugian karena keberadaan satu ekor spesies $P$. clarkii adalah sebesar Rp 1416.76 karena hilangnya $M$. rosenbergii akibat kompetisi makanan. Berdasarkan analisis ini, pendugaan kerugian spesies invasif dengan pendekatan kompetisi makanan dapat dilakukan untuk menggambarkan kerugian dengan lebih mudah dipahami. Untuk pendugaan ini diperlukan dua komponen pokok yaitu: (1) model biologi yang mengestimasi model pertumbuhan dan kebutuhan makanan sebagai komponen bio-ekologi dan (2) harga komoditas sebagai komponen ekonomis. Semakin akurat model biologinya, maka estimasi kerugian ekonomi akan semakin baik.

\section{UCAPAN TERIMA KASIH}

Penulis mengucapkan terima kasih kepada Direktorat Jenderal Penguatan Riset dan Pengembangan, Kementrian Riset Teknologi, dan Pendidikan Tinggi atas biaya penelitian sesuai dengan Surat Perjanjian Penugasan Pelaksanaan Program Penelitian Nomor: 011/SP2H/LT/DRPM/1V/2017 tanggal 20 April 2017.

\section{DAFTAR PUSTAKA}

Afni K. 2008. Analisis kelayakan pengusahaan lobster air tawar (kasus K'BLAT'S Farm, Kec. Gunung Guruh, Kab. Sukabumi, Jawa Barat) [skripsi]. Bogor (ID): Institut Pertanian Bogor.

Ahyong ST, Yeo DCJ. 2007. Feral populations of the Australian Red-Claw crayfish (Cherax quadricarinatus von Martens) in water supply catchments of Singapore. Biol Invasions. 9: 943-946.

Aini N, Kusumastanto T, Adrianto L, Sadelie A. 2018. Identifikasi aktivitas ekonomi dan nilai ekonomi spasial DAS Ciliwung. Jurnal Pengelolaan Sumber Daya Alam dan Lingkungan. 8(2): 223-234.

Aprila LS. 2018. Perbandingan antara dinamika populasi Macrobrachium sintangense (de Man, 1898) dan M. lanchesteri (de Man, 1911) di Danau Lido, Jawa Barat [tesis]. Bogor (ID): Institut Pertanian Bogor.

Cadotte MW. 2006. Darwin to Elton: Early ecology and the problem of invasive species. In: Cadotte MW, McMahon SM, Fukami T, editors. Conceptual Ecology and Invasion Biology: Reciprocal Approaches to Nature. Dordrecht (NL): Springer.

Charles H, Dukes JS. 2007. Impacts of invasive species on ecosystem services. In: Nentwig W, editor. Biological Invasion. Berlin (DE): Springer.

Effendi MI. 2002. Biologi Perikanan. Yogyakarta (ID): Yayasan Pustaka Nusa Tama.

Epanchien-Niell RS. 2017. Economics of invasive species policy and management. Biol Invasion. 19: 33333354.

Essl F, Hulme PE, Jeschke JM, Keller R, Pysek P, Richardson DM, Saul WF, Bacher S, Dullinger S, Esteves RA, Kueffer C, Roy HE, Seebens H, Rabitsch W. 2017. Scientific and normative foundation for the valuation of alie-species impacts: thirteen core principles. BioScience. 67(2) :166-178.

Gallardo B, Zieritz A, Aldrigde DC. 2015. The importance of human footprint in shaping the global distribution of terrestrial, freshwater and marine Invaders. PLOS ONE. 10(5): 1-17. doi: doi.org/10.1371/journal.pone.0125801.

Gherardi F, Acuistapace. 2007. Invasive crayfish in Europe: the impact of Procambarus clarkii on the littoral community of a Mediteranian lake. Freshw Biol. (52)7: 1249-1259.

Hanley N, Robert M. 2019. The economic benefits of invasive species management. People Nat. 1: 124-137. 
Hermanto D, Kusumastanto T, Adrianto L, Supartono. 2019. Pengelolaan sumberdaya perikanan tangkap berbasis daya dukung lingkungan perairan di WPPNRI 711. Jurnal Pengelolaan Sumber Daya Alam dan Lingkungan. 9(1): 105-113.

Hestimaya E. 2010. Studi ikhtiofauna di Danau Lido, Kabupaten Bogor Jawa Barat [skripsi]. Bogor (ID): Institut Pertanian Bogor.

Huang J, Zhou K, Zhou, Zhang W, Deng X, van der Werf W, Lu Y, Wu K, Rosegrant MW. 2018. Uncovering the economic value of natural enemies and true cost of chemical insecticides to cotton farmer in China. Environ. Res. Lett. 13: 064027.

Kunwar RM, Acharya RP. 2013. Impact Assessment of invasive Plant Species in Selected Ecosystems of Bhadaure Tamagi VDC Kaski, an Ecosystem-Based Adaptation in Mountain Ecosystem Nepal. Nepal: IUCN.

Lodge DM, Taylor CA, Holdich DM, Skurdal. 2000. Nonindigenous crayfishes threaten North American freshwater biodiversity: lessons from Europe. Fisheries. 25(8): 7-20.

Lodge DM, Deines A, Gherardi F, Yeo DCT, Arcella T, Baldridge AK, Barnes MA, Chadderton WL, Feder JL, Gantz CA, Howard GW, Jerde CL, Peters BW, Peters JA, Sargent LW, Turner CR, Wittmann ME, Zeng Y. 2012. Global introduction of crayfishes: evaluating the impact of spesies invasion on ecosystem services. Annu Rev Ecol Evol Syst. 43: 449-472.

Lovell SJ, Stone SF. 2005. The Economic of Aquatic Invasive Species: A Review of the Literatur. Washington DC (US): Natural Center for Environmental Economic (NCEE).

Ludsin SA, Wolfe AD. 2001. Biological invasion theory: Darwin's contribution from The Origin of Species. Bio Sci. 51(9): 780-789.

Mayasari N, Said DS. 2014. Pola pertumbuhan Macrobrachium sintangense pada pemberian pakan yang diperkaya dengan Spirulina sp. Prosiding Seminar Nasional Limnologi VII. LIPI. 149-157.

Mostert E, Gaertner M, Holmes PM, Rebelo AG, Richardson DM. 2013. Impact of invasive alien trees on threatened lowland vegetation types in the Cape Floristic Region, South Africa. S. Afr. J. Bot. 108: 209222.

Nunes AL, Zengeya TA, Hoffman AC, Measey GJ, Weyl OLF. 2017. Distribution and establishment of the alien Australian redclaw crayfish, Cherax quadricarinatus, in South Africa and Swaziland. PeerJ. 5: e3135. doi: doi.org/10.7717/peerj.3135.

Ogle D. 2013. fishR Vignette - Open Mark-Recapture Abundance Estimates [Internet]. [diunduh 2020 Mei 2]. Tersedia pada: http://derekogle.com/fishR/examples/oldFishRVignettes/MROpen.pdf.

Patoka J, Wardiatno Y, Yonvitner, Kuříková P, Petrtýl M, Kalous L. 2016. Cherax quadricarinatus (von Martens) has invaded Indonesian territory west of the Wallace Line: evidences from Java. Knowl. Manag. Aquat. Ecosyst. 417: 39. doi: 10.1051/kmae/2016026.

Perring C, Williamson M, Barbier EB, Delfino D, Dalmazzone S, Shogren J, Simmons P, Watkinson A. 2002. Biological invasion risks and the public good: An economic perpective. Ecol. Soc. 6(1): 181-189.

Putra MD, Bláha M, Wardiatno Y, Krisanti M, Yonvitner, Jerikho R, Kamal MM, Mojžišová M, Bystřický PK, Kouba A, Kalous L, Petrusek A, Patoka J. 2018. Procambarus clarkii (Girard, 1852) and crayfish plague as newthreats for biodiversity in Indonesia. Aquatic Conserv. Mar. Freshw. Ecosyst. 28(6): 14341440 .

Rihardi I, Amir S, Abidin Z. 2013. Pertumbuhan lobster air tawar (Cherax quadricarinatus) pada pemberian makanan dengan frekuensi yang berbeda. Jurnal Perikanan Unram.1(2): 28-36.

Romaire RP. 2017. 2017 Coastal Master Plan: Attachment C3-19: Crayfish, Procambarus clarkii and P. zonangulus, Habitat Suitability Index Model. Version Final. Baton Rouge, Louisiana (UK): Coastal Protection and Restoration Authority.

Russel JC, Meye JY, Holmes ND, Pagad S. 2017. Invasive alien species on island: impacts, distribution, interaction and management. Environ. Conserv. 44(4): 359-370. 
Said D, Mayasari N, Wowor D, Sahroni, Triyanto, Lukman, Ali F, Maghfiroh M, Akhdiana I. 2014. Udang Regang: Potensi dan Pengembangan. Bogor (ID): Pusat Penelitian Limnologi dan Pusat Penelitian Biologi. Lembaga Ilmu Pengetahuan Indonesia.

Sarat E, Mazaubert E, Dutartre A, Poulet N, Soubeyran Y. 2015. Invasive Alien Species in Aquatic Environments: Practical Information and Management Insights. Perancis (FR): The French National Agency for Water and Aquatic Environments (Onema).

Solano JCA, Elizondo BN, Carranza AHR, Fonseca MC. 2017. Presence of the Australian redclaw crayfish Cherax quadricarinatus (von Martens, 1868) (Parastacidae, Astacoidea) in a freshwater system in the Caribbean drainage of Costa Rica. BioInvasions Rec. 6(4): 351-355.

Sparre P, Venema SC. 1999. Introduksi Pengkajian Stok Ikan Tropis. Edisi terjemahan. Jakarta (ID): Kerjasama Organisasi Pangan, Perserikatan Bangsa-Bangsa dengan Pusat Penelitian dan Pengembangan Perikanan, Badan Penelitian dan Pengembangan Pertanian.

Spatz DR, Zilliacus KM, Holmes ND, Butchart SHM, Genovesi P, Ceballos G, Tershy BR, Croll DA. 2017. Globally threatened vertebrates on island with invasive species. Sci. Adv. 3: e1603080.

Tahir AG, Pasaribu AM. 2003. Kajian adaptasi udang galah (Macrobrachium rosenbergii) dan ikan mas (Cyprinus carpio) dengan sistem mina padi jajar legowo di lahan sawah irigasi. Jurnal Pengkajian dan Pengembangan Teknologi Pertanian. 6(2): 167-175.

Tjahjo DWH, Boer M, Affandi R, Muchsin I, Soedarma D. 2004. Evaluasi penebaran udang galah (Macrobrachium rosenbergii) di Waduk Darma, Jawa Barat. Jurnal Ilmu-Ilmu Perairan dan Perikanan Indonesia. 11(2): 101-107.

Taylor CA, Warren Jr ML, Fitzpatrick Jr JF, Hobbs HH, Jezerinac RF, Pflieger WL, Robinson HW. 1996. Conservation status of crayfishes of the United States and Canada. Fisheries. 21(4): 25-38.

Taylor CA, Schuster GA, Cooper JE, DiStefano RJ, Eversole AG, Hamr P, Hobbs III HH, Robinson HW, Skelton CE, Thoma RE. 2007. Reassessment of the conservation status of crayfishes of the United States and Canada after 10+ years of increased awareness. Fisheries. 32(8): 372-379.

Turbelin AJ, Malamud BD, Francis RA. 2017. Mapping the global state of invasive alien species: patterns of invasion and policy responses. Global Ecol. Biogeogr. 26: 78-92.

Xiao X, Han D, Zhu Xiaoming, Yang Y, Xie S, Huang Y. 2014. Effect of dietary cornstarch levels on growth performance, enzyme activity and hepatopancreas histology of juvenile red swamp crayfish, Procambarus clarkii (Girard). Aquaculture. 426-427: 112-119.

Wato J, Okoth E. 2014. Dietary diversity of crayfish (Procambarus clarkii Girard 1852) (Crustacea, Decapoda) in herbaceous vegetation dominated swamps in Uasin Gishu, Kenya. Int. J. Sci. Res. 3(9): 1204-1207. 